\title{
Seroprevalence of Hepatitis B infection among pregnant women in South India
}

\author{
Sathiyakala Rajendiran, Ushadevi Gopalan*, Karthika Jayakumar
}

\begin{abstract}
Department of Obstetrics and Gynecology, Shri Sathya Sai Medical College and Research Institute, Ammapettai, Kancheepuram, Tamilnadu, India
\end{abstract}

Received: 10 November 2016

Accepted: 03 December 2016

*Correspondence:

Dr. Ushadevi Gopalan,

E-mail: ushag7@hotmail.com

Copyright: (c) the author(s), publisher and licensee Medip Academy. This is an open-access article distributed under the terms of the Creative Commons Attribution Non-Commercial License, which permits unrestricted non-commercial use, distribution, and reproduction in any medium, provided the original work is properly cited.

\begin{abstract}
Background: Vertical transmission of infection from mother to infants is a very important route of transmission of hepatitis B virus. Hepatitis B virus infection in pregnant women usually goes undetected. The hepatitis B surface antigen in serum is the first seromarker to indicate active HBV infection. This study was done to determine the seroprevalence of HBsAg in healthy asymptomatic antenatal women.

Methods: It was a hospital based study over a period of two years. A total of 1282 antenatal patients were tested for hepatitis B surface antigen.

Results: The prevalence rate of HBsAg was found to be $1.01 \%$ ( 13 positive out of 1282 cases). Highest prevalence was in age group 26-30(46\%) followed by age group 31-35(30.8\%) followed by age group 20-25 yrs (23.1\%).

Conclusions: Screening of all pregnant women for HBV irrespective of risk factors will reduce the prevalence and risks of $\mathrm{HBV}$ infection.
\end{abstract}

Keywords: Hepatitis B surface antigen, Pregnant women, Perinatal transmission, Seroprevalence

\section{INTRODUCTION}

Hepatitis B virus infection occurs globally and constitutes a major public health problem. ${ }^{1}$ Over 20 million people are infected globally with this virus every year and there are around 350-400 million chronic carriers of hepatitis B virus. $^{2}$ More than 1.2 million deaths occur annually from HBV related disease making HBV infection the $10^{\text {th }}$ leading cause of death globally. ${ }^{3,4}$ It has been estimated that up to $10 \%$ of the 350 million hepatitis B chronic carriers are in India. The carrier rate of hepatitis B in India may vary in the different regions and is being quoted as being $4.7 \% .^{5,6}$ Hepatitis B infection leads to a wide spectrum of clinical presentations ranging from asymptomatic carrier state to acute self-limiting infections or fulminating hepatic failure, chronic hepatitis with progression to cirrhosis and hepatocellular carcinoma. ${ }^{7}$ The hepatitis B surface antigen ( $\mathrm{HBsAg}$ ) in serum is the first seromarker to indicate active $\mathrm{HBV}$ infection either acute or chronic. ${ }^{8}$ Hepatitis B virus (HBV) infection usually goes undetected. Unawareness of an on-going infection delays the diagnosis of HBV related liver disease and favours the spread of the virus. ${ }^{9}$ Pregnant women are a vulnerable group and there is risk of transmitting infection to the new-born if mother is infectious. Vertical transmission of infection from mother to infants is a very important route of transmission of HBV. ${ }^{10}$ Fetal and neonatal hepatitis acquired from mother during pregnancy leads to impaired cognitive and physical development in later life of the children. ${ }^{11}$ In the absence of immunoprophylaxis $10-20 \%$ of women seropositive for HBsAg transmit the virus to their neonates. ${ }^{12}$ Effective strategies for reducing incidence of chronic infections include maternal screening combined with post exposure prophylaxis consisting of $\mathrm{HBV}$ vaccination immediately after delivery in all children born to HBsAg positive mothers ideally with immunoglobulin prophyaxis. ${ }^{13}$ Several studies worldwide 
have recommended that pregnant women should be screened for hepatitis B before delivery as this offers an opportunity to prevent another generation from being chronically infected by the virus. ${ }^{14}$ Hence this study was done to determine the seroprevalence of HBsAg in otherwise healthy antenatal women.

\section{METHODS}

This study was conducted in the obstetrics and gynaecology department in a tertiary level teaching hospital for a period of two years from October 2014 to September 2016. Hepatitis B surface antigen (HBsAg) was determined to be the serological marker for the viral infection among antenatal women.All pregnant women attending the antenatal outpatient department were offered the test and were included in the study if they agreed to participate .Informed consent was taken. A total of 1282 antenatal women were tested for hepatitis B surface antigen using sandwich ELISA immunoassay and results obtained.

\section{RESULTS}

A total of 1282 cases in the age group of 20-35 years who attended the antenatal outpatient department in the study period were included. Out of these 1282 cases 13 antenatal women were found to be seropositive for HBsAg. The prevalence rate was found to be $1.01 \%$.

Table 1: HBsAg - Age specific seroprevalence.

\begin{tabular}{|ll|}
\hline Age Group (years) & $\begin{array}{l}\text { No. of HBsAg positive cases } \\
(\%)\end{array}$ \\
\hline $20-25$ & $3(23.1 \%)$ \\
\hline $26-30$ & $6(46.1 \%)$ \\
\hline $31-35$ & $4(30.8 \%)$ \\
\hline
\end{tabular}

The highest prevalence was observed in the age group 26-30 years $(46.1 \%)$,followed by the age group 31 35 years $(30.8 \%)$,followed by the age group 20-25years $(23.1 \%)$. One of the patients who tested seropositive for HBsAg had tested positive for HIV infection also. All the women who tested seropositive for $\mathrm{HBsAg}$ were followed up till delivery and the baby received joint administration of hepatitis $B$ vaccine and specific immunoglobulin in the early neonatal period to prevent the mother/child transmission of the virus.

\section{DISCUSSION}

Screening asymptomatic people is an important instrument of disease detection, prompt diagnosis and intervention especially concerning a typically asymptomatic infection such as chronic HBV infection itself. $^{15}$ The USPSTF $^{16}$ recommends screening for hepatitis $\mathrm{B}$ virus (HBV) infection in pregnant women at their first prenatal visit. In the present study the seroprevalence of HBsAg among pregnant women was found to be $1.01 \%$. This is comparable to the seroprevalence of $0.9 \%$ reported by Dwivedi $\mathrm{M}$ and colleagues, $0.61 \%$ reported in a study by Parveen $\mathrm{S}$ et al, $0.82 \%$ reported by Chaterjee $\mathrm{S}$ et al, $1.1 \%$ reported by Pandy et al and $1.11 \%$ reported by Sibia $\mathrm{P}$ et al. ${ }^{17-21}$ Lodha et al in their review article on hepatitis B epidemiology have suggested the prevalence rate in India as $1-2 \% .^{5}$ In our country in the different regions there is a wide variation in prevalence and a high prevalence has been reported by Prakash et al in North India $(9.5 \%) .^{22}$ An extensive review by INASL has arrived at a consensus figure of $4.7 \%$ as the national average for carrier state. ${ }^{23}$ A systematic review of prevalence of hepatitis B in India by Ashish Batham et al found the point prevalence among non-tribal population is $2-4 \%$ and the point prevalence among tribal population is 15.8 $\% .^{6}$ In our study the prevalence of HBV infection was highest in the age group 26-30(46.1\%). Pontius Bayo et $\mathrm{al}^{24}$ found that the prevalence of $\mathrm{HBV}$ infection was higher among women aged 20 years or younger(20\%) compared with the older women while Frambo AAB et al found that the highest prevalence was in age group 15-19 (20\%) followed by age group $30-34(13.64 \%) .{ }^{15}$ Sibia P et al found 25-30 years to be the most common age group with HBV infection. ${ }^{21}$ The infants born to seropositive HBsAg mothers should receive $0.5 \mathrm{ml}$ Hepatitis B Immunoglobulin and Hepatitis B vaccine within 12 hours of birth. ${ }^{16}$ Between $30-40 \%$ of all chronic HBV infection results from perinatal transmission. The USPSTF found convincing evidence that universal prenatal screening for HBV infection substantially reduces perinatal transmission of $\mathrm{HBV}$ and the subsequent development of chronic HBV infection. They also found no published studies that describe harms of screening for $\mathrm{HBV}$ infection in pregnant women ${ }^{16}$.In order to prevent perinatal transmission and spread of infection within the larger community, pregnant mothers should be screened for hepatitis B. Neonates who are infected by hepatitis B will have an almost $90 \%$ risk of developing chronic hepatitis B surface antigen carriage and chronic liver disease. ${ }^{18}$ A number of limitations are there in this study. Only HBsAg was tested as marker for hepatitis B infection. If other markers were combined with $\mathrm{HBsAg}$ the study would have been more informative and reliable. This study only determined the seroprevalence of HBsAg in pregnancy in our area. As vertical transmission is responsible for majority of $\mathrm{HBsAg}$ infections it may be enough if we screen all antenatal women and give combined immunization and immunoprophylaxis to the high risks infants born to the seropositive mothers. However in a country like India where a large number of deliveries are still non-institutional this high risk strategy may not be feasible. ${ }^{25}$

\section{CONCLUSION}

Screening of all pregnant women for HBV infection irrespective of risk factors and increasing awareness about HBV infection will reduce the prevalence and risk of $\mathrm{HBV}$ infections. If the pregnant women are not diagnosed and managed properly, the future burden of the 
disease for society and health care resources will be very high.

\section{Funding: No funding sources Conflict of interest: None declared Ethical approval: Not required}

\section{REFERENCES}

1. WHO: Hepatitis B. Fact Sheet No.204. Geneva, Switzerland: World Health Organization. 2011.

2. Alam MM, Zaidi SZ, Malik SA, Naeem A, Shaukat S, Sharif S, et al. Serology based disease status of Pakistani population infected with Hepatitis B virus. BMC Infectious Diseases. 2007;7:64.

3. Teo E-K, Lok ASF. Epidemiology, transmission and prevention of hepatitis B virus infection. In Up-todate. Edited by Basow DS. Waltham, MA: Up to Date: 2009.

4. World Health Organization. Hepatitis B vaccines. Wkly Epidemiol Rec. 2009;40:405-20.

5. Lodha R, Jain Y, Anand K, Kabra SK, Pandav CS. Hepatitis B in India: A review of disease epidemiology. Indian Pediatrics. 2001;38(4):349-71.

6. Batham A, Narula D, Toteja T, Sreenivas V, Puliyel JM. Systematic review and meta-analysis of prevalence of hepatitis B in India. Indian Pediatrics. 2007:44(9):663-74.

7. Zhu R, Zhang H, Yu H, Li H, Ling YQ, Hu XQ. Pathol Res Pract. 2008;204:731-42.

8. Horvat RT, Tegtmeier GE. Hepatitis B and D viruses. Manual of Clinical Microbiology. In: Murray PR, Baron EJ, Jorgensen JH, Pfaller MA and Yolken RH.editors. Washington D.C: ASM Press. 2003:1464-78.

9. Vazquez-Martinez JL, Coreno-Juarez MO, MontanoEstrada LF, Attlan M, Gomez-Dantes $\mathrm{H}$. Seroprevalencia de hepatitis B en mujeres embarazadas en Mexico. Salud Publica Mexico. 2003;45:165-70.

10. Schweitzer IL. Vertical transmission of hepatitis B surface antigen. Am J Med Sci. 1975;270:287-91.

11. Olaitan AO, Zamani LG. Prevalence of hepatitis B virus and hepatitis $\mathrm{C}$ virus in antenatal-patients in Gwagwalada-Abuja, Nigeria. Report and Opinion. 2010;2(7):48-50.

12. Viral hepatitis in pregnancy. Obstetrics and Gynecology. ACOG Practice bulletin No.86. 2007;110(4):941-56.

13. Lee C, Gong Y, Brok J, Boxall EH, Gluud C. Effect of hepatitis $\mathrm{B}$ immunization in newborn infants of mothers positive for hepatitis B surface antigen: systematic review and meta-analysis. BMJ. 2006;332(7537):328-36.

14. Yohanes T, Zerdo Z. Seroprevalence and Predictors of hepatitis B Virus Infection among Pregnant Women attending Routine Antenatal Care in Arba Minch Hospital , South Ethiopia. Hepatitis Research and Treatment. 2016: article ID: 9290163.

15. Atashili J. Prevalence of HBsAg and knowledge about hepatitis B in pregnancy in the Buea Health District, Cameroon: a cross-sectional study. BMC Research Notes. 2014;7:394.

16. Screening for Hepatitis B Virus Infection in Pregnancy: U.S. Preventive services task Force Reaffirmation Recommendation Statement. Annals of internal Medicine. 2009;150(12):869-74.

17. Dwivedi M, Misra SP. Seroprevalence of hepatitis B infection during pregnancy and risk of perinatal transmission. Indian J Gastroenterol. 2011;30:66.

18. Shyamala R, Janardhan Rao R. Seroprevalence of Hepatitis B surface antigen among pregnant women attending antenatal clinic in a teaching hospital. J Microbiol Biotech Res. 2012;2(2):343-5.

19. Chatterjee S, Ravishankar K, Chaterjee R, Narang A, Kinikar A. Hepatitis B prevalence during pregnancy. Indian Pediatr. 2009;46:1005-8.

20. Pande C, Sarin SK, Patra S. Prevalence, risk factors and virological profile of chronic hepatitis $\mathrm{B}$ virus infection in pregnant women in India. J Med Virol. 2011;83:962-7.

21. Sibia P. Seroprevalence of Hepatitis B Infection among Pregnant Women in One of the Institute of Northern India. Journal of Clinical and Diagnostic Research. 2016;10(8):QC08-9.

22. Prakash C, Sharma RS, Bhatia R, Verghese T, Datta KK. Prevalence of North India of hepatitis B carrier state amongst pregnant women. Southeast Asian J Trop Med Public Health. 1998;29:80-4.

23. Indian Association for Study of the Liver (INSAL). Hepatitis B in India; therapeutic options and prevention strategies-Consensus statement .Indian J Gastroenterol. 2000;19:C4-66.

24. Bayo P, Ochola E. High Prevalence of hepatitis B virus infection among pregnant women attending antenatal care: a cross-sectional study in two hospitals in Northern Uganda. BMJ Open. 2014;4:e005889.

25. Chakravarti D, Rawat M. A Study on the perinatal transmission of the hepatitis B virus. Indian Journal of Medical Microbiology. 2005;23(2):128-30.

Cite this article as: Sathiyakala $R$, Ushadevi $G$, Karthika J. Seroprevalence of Hepatitis B infection among pregnant women in South India. Int J Reprod Contracept Obstet Gynecol 2017;6:249-51. 